\title{
PENGARUH VARIASI KECEPATAN UDARA TERHADAP KINERJA TUNGKU GASIFIKASI SEKAM PADI TIPE DOWNDRAFT KONTINU
}

\author{
Subroto, Nurhadi Saputra \\ Teknik Mesin Universitas Muhammadiyah Surakarta \\ Jl. A Yani Tromol Pos 1 Pabelan Surakarta \\ E-mail:subroto@ums.ac.id
}

\begin{abstract}
ABSTRAK
Gasifikasi adalah suatu proses perubahan bahan bakar padat secara termokimia menjadi gas, dengan cara mengendalikan udara yang diperlukan lebih rendah dari udara yang digunakan untuk proses pembakaran. Tujuan penelitian ini adalah untuk mengetahui pengaruh kecepatan udara pembakaran terhadap kinerja pada tungku gasifikasi tipe downdraft .Kinerja tungku meliputi karakteristisik temperatur pembakaran, waktu penyalaan awal dan lamanya waktu pembakaran atau waktu nyala efektif. Penelitian dilakukan dengan cara memvariasikan kecepatan udara yang masuk kedalam tungku dengan variasi kecepatan $6,0 \mathrm{~m} / \mathrm{s}, 7,0 \mathrm{~m} / \mathrm{s}$ dan $8,0 \mathrm{~m} / \mathrm{s}$, data yang diambil meliputi temperatur pembakaran, waktu penyalaan awal dan lama waktu nyala efektif. Hasil penelitian menunjukkan variasi kecepatan udara berpengaruh terhadap temperatur pembakaran, waktu penyalaan awal dan lama waktu nyala efektif yang dihasilkan. Temperatur pembakaran tertingi pada kecepatan udara $8 \mathrm{~m} / \mathrm{s}, 7 \mathrm{~m} / \mathrm{s}, 6 \mathrm{~m} / \mathrm{s}$ sedangkan waktu penyalan tercepat pada kecepatan udara $8 \mathrm{~m} / \mathrm{s}, 7 \mathrm{~m} / \mathrm{s}, 6 \mathrm{~m} / \mathrm{s}$ dan lama waktu nyala efektif pada kecepatan udara $6 \mathrm{~m} / \mathrm{s}, 7 \mathrm{~m} / \mathrm{s}$ $8 \mathrm{~m} / \mathrm{s}$
\end{abstract}

Kata kunci: Gasifikasi, downdraft kontinu, kinerja, kecepatan udara

\section{PENDAHULUAN}

Kebutuhan akan energi menjadi hal yang sangat penting bagi kelangsungan hidup manusia, sampai saat ini sebagian besar energi yang dibutuhkan masih berasal dari sumbersumber energi yang tidak terbarukan yang jumlahnya semakin hari semakian menipis.

Cadangan minyak yang dimiliki Indonesia diperkirakan tidak akan bertahan lebih dari 11 tahun. Hal ini terjadi jika laju produksi minyak Indonesia terus berada pada kisaran 800 ribu barel per hari (bph). Sekretaris SKK Migas Gde Pradyana mengatakan, masyarakat seharusnya menyadari Indonesia saat ini tidak lagi kaya akan sumber daya energi fosil seperti minyak bumi. Semakin menipisnya cadangan energi yang dimiliki serta semakin bertambah tingginya tingkat konsumsi dari masyarakat membuat impor terhadap komoditas energi tidak dapat dihindari, pemenuhan kebutuhan energi dengan jalan impor ini tentu memiliki banyak konsekuensi negatif yang harus ditanggung yaitu harga yang tidak setabil dan besarnya tambahan biaya untuk mendatangkan sumber energi tersebut, dampaknya adalah biaya yang harus dikeluarkan untuk memperoleh energi tersebut menjadi tinggi.

Energi alternatif yang terbarukan adalah salah solusi yang bisa membantu untuk mengatasi semakin menipisnya cadangan energi. Banyak sekali metode atau cara yang bisa diterapkan untuk memperoleh sumber-sumber energi alternatif salah satunya yaitu dengan metode 
gasifikasi. Gasifikasi adalah proses perubahan bahan bakar padat secara termokimia menjadi bahan bakar gas, dimana udara yang diperlukan lebih rendah dari udara yang digunakan untuk proses pembakaran. Proses gasifikasi ini dapat memanfaatkan banyak bahan-bahan yang seringkali dikategorikan sebagai sampah/bahan-bahan yang tidak lagi terpakai seperti, sekam padi, serbuk gergaji, batok kelapa, dan lain-lain. Selain bisa menghasilkan sumber energi proses ini juga bisa membantu mengurangi penanggulangan sampah.

Proses gasifikasi menghasilkan gas-gas yang sifatnya mudah terbakar yaitu $\mathrm{CH} 4$ (Metana), H2 (Hidrogen) dan CO (karbon monoksida), sehingga bisa menggantikan fungsi dari bahan bakar. Oleh karena itu penelitian dan pengembangan teknologi gasifikasi sebagai salah satu sumber energi alternatif harus terus menerus ditingkatkan agar bisa mendapatkan efisiensi dan efektivitas yang paling maksimal.

Berdasarkan arah alirannya gasifikasi dibedakan menjadi gasifikasi downdraft, updraft dan crosdraft, gasifikasi tipe downdraft adalah gasifikasi yang memiliki arah padatan dan aliran udara yang sama yaitu ke bawah menuju zona gasifikasi yang panas, hal ini memungkinkan tar yang terdapat pada asap terbakar sehingga gas yang dihasilkan lebih bersih. Keuntungan gasifikasi tipe downdraft adalah dapat dioperasikan secara berkesinambungan dengan cara menambahkan bahan bakar melalui bagian atas reaktor.

Udara merupakan komponen utama dalam proses pembakaran gasifikasi, kecepatan udara yang masuk tungku sangat berpengaruh terhadap efektivitas pembakaran untuk itu perlu dilakukan penelitian terhadap kecepatan udara yang paling efektif untuk digunakan.

\section{TUJUAN PENELITIAN}

1. Untuk mengetahui pengaruh variasi kecepatan udara terhadap temperatur pembakaran.

2. Untuk mengetahui pengaruh variasi kecepatan udara terhadap waktu penyalaan awal.

3. Untuk mengetahui pengaruh variasi kecepatan udara terhadap waktu nyala efektif.

\section{TINJAUAN PUSTAKA}

Lailun Najib, Sudjud Darsopuspito (2012), melakukan penelitian Karakterisasi Proses Gasifikasi Biomassa Tempurung Kelapa Sistem Downdraft Kontinu Dengan Variasi Perbandingan Udara-Bahan Bakar $(A F R)$ Dan Ukuran Biomassa. Hasil pengujian menunjukkan bahwa semakin besar AFR (Air Fuel Ratio) maka semakin kecil komposisi flammable gas (gas yang mudah terbakar), hal ini dikarenakan besarnya laju aliran udara yang masuk ke dalam tungku tidak sebanding dengan laju aliran biomassa yang dihasilkan sehingga udara yang masuk ke dalam tungku gasifikasi menjadi berlebih, maka akan terbentuk banyak gas $\mathrm{O}_{2}, \mathrm{~N}_{2}, \mathrm{CO}_{2}$ dan Flammable gas $\left(\mathrm{H}_{2}, \mathrm{CO}, \mathrm{CH}_{4}\right)$ berkurang [1].

Budi Setiawan (2014), melakukan pengujian gasifikasi batu bara dengan mengunakan tungku gasifikasi tipe up draft dengan variasi kecepatan udara untuk keperluan karbonasi. Pengujian menggunakan variasi kecepatan udara 2,0 m/s, 4,0 m/s dan $6,0 \mathrm{~m} / \mathrm{s}$, hasil pengujian menyatakan bahwa variasi udara berpengaruh terhadap temperatur pembakaran, dari pengujian diperoleh data bahwa kecepatan udara $6,0 \mathrm{~m} / \mathrm{s}$ yaitu memiliki temperatur sebesar $369^{\circ} \mathrm{C}$, kecepatan udara $4,0 \mathrm{~m} / \mathrm{s}$ memiliki temperatur sebesar $294^{\circ} \mathrm{C}$ dan kecepatan udara $2,0 \mathrm{~m} / \mathrm{s}$ sebesar $232^{\circ} \mathrm{C}$ [2].

Handoyo (2013), melakukan pengujian gasifikasi sekam padi dengan menggunakan tungku tipe up draft dengan variasi kecepatan udara terhadap temperatur pembakaran dengan bahan bakar sekam padi. Pengujian menggunakan variasi kecepatan udara $3,5 \mathrm{~m} / \mathrm{s}$, $4,0 \mathrm{~m} / \mathrm{s}$ dan $4,5 \mathrm{~m} / \mathrm{s}$, dari ketiga variasi kecepatan tersebut hasil pengujian menunjukkan bahwa semakin tinggi kecepatan udara yang digunakan maka semakin tinggi temperatur yang dihasilkan [3]. 


\section{Biomassa}

Biomassa adalah bahan organik yang dihasilkan melalui proses fotosintetik, baik berupa produk maupun buangan. Contoh biomassa antara lain adalah daun tanaman, pepohonan, rumput, limbah pertanian, limbah hutan, tinja dan kotoran ternak. Selain digunakan untuk tujuan primer serat, bahan pangan, pakan ternak, minyak nabati, bahan bangunan dan sebagainya, biomassa juga digunakan sebagai sumber energi (bahan bakar). Yang digunakan untuk bahan bakar adalah biomassa yang nilai ekonomisnya rendah atau merupakan limbah setelah diambil produk primernya.

Energi biomassa dapat menjadi sumber energi alternatif pengganti bahan bakar fosil (minyak bumi) karena beberapa sifatnya yang menguntungkan yaitu, dapat dimanfaatkan secara lestari karena sifatnya yang dapat diperbaharui (renewable resources), relatif tidak mengandung unsur sulfur sehingga tidak menyebabkan polusi udara dan juga dapat meningkatkan efisiensi pemanfaatan sumber daya hutan dan pertanian [4].

\section{Gasifikasi}

Gasifikasi adalah suatu proses perubahan bahan bakar padat secara termokimia menjadi gas, dimana udara yang diperlukan lebih rendah dari udara yang digunakan untuk proses pembakaran. Produk yang dihasilkan dapat dikategorikan menjadi tiga bagian utama, yaitu: padatan, cairan dan gas permanen.

Gas hasil gasifikasi terdiri dari gas-gas yang dapat/mudah dibakar yaitu $\mathrm{CO}, \mathrm{H}_{2}$ dan $\mathrm{CH}_{4}$, pengotor inorganic berupa gas-gas yang tidak dapat terbakar seperti $\mathrm{CO}_{2}, \mathrm{~N}, \mathrm{NH}_{3}$, $\mathrm{HCN}, \mathrm{H}_{2} \mathrm{~S}$ serta debu halus dan pengotor organik yaitu Tar. Komposisi gas yang terkandung sangat tergantung pada komposisi dari unsur yang digunakan sebagai bahan bakar.

\section{Jenis-jenis Gasikasi}

Berdasarkan arah aliran Gasikasi dapat dibedakan menjadi beberapa macam, yaitu:

a. Gasifiksi aliran searah (Downdraft gasification) yaitu arah aliran padatan dan gas samasama kebawah.

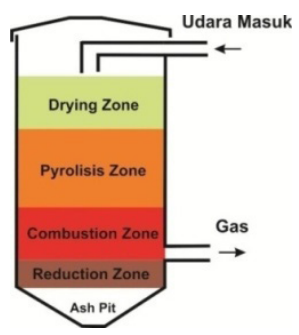

Gambar 1. Gasifikasi Downdraft [5]

b. Gasifikasi aliran berlawanan (Updraft gasification) yaitu arah aliran padatan kebawah sedangkan arah aliran gas keatas.

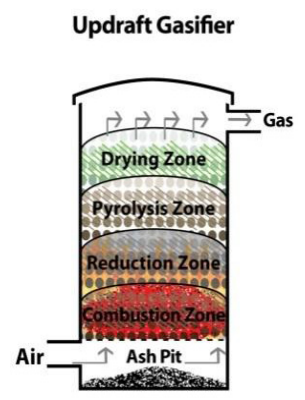

Gambar 2. Gasifikasi Updraft [5] 
c. Gasifikasi Crosdraft yaitu arah aliran gas dijaga mengalir mendatar dengan aliran padatan kebawah.

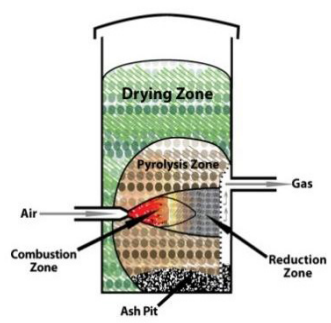

Gambar 3. Gasifikasi Crosdraft [5]

\section{Tahapan Proses Gasifikasi}

a. Drying atau pengeringan $\left(\mathrm{T}>150^{\circ} \mathrm{C}\right)$

Pada tahap pengeringan, kandungan air pada bahan bakar padat diuapkan oleh panas yang diserap dari proses oksidasi.

b. Pirolisis atau devolatilisasi $\left(150^{\circ} \mathrm{C}<\mathrm{T}<550^{\circ} \mathrm{C}\right)$

Pirolisis atau devolatilisasi disebut juga sebagai gasifikasi parsial. Suatu rangkaian proses fisik dan kimia terjadi selama proses Pirolisis yang dimulai secara lambat pada $\mathrm{T}$ $<100^{\circ} \mathrm{C}$ dan terjadi secara cepat pada $\mathrm{T}>200^{\circ} \mathrm{C}$. Proses Pirolisis dimulai pada temperatur sekitar $230^{\circ} \mathrm{C}$. Produk Pirolisis umumnya terdiri dari tiga jenis, yaitu gas ringan $\left(\mathrm{H}_{2}, \mathrm{CO}\right.$, $\mathrm{CO}_{2}, \mathrm{H}_{2} \mathrm{O}$ dan $\left.\mathrm{CH}_{4}\right)$, tar dan arang.

c. Oksidasi atau pembakaran $\left(70^{\circ} \mathrm{C}<\mathrm{T}<150^{\circ} \mathrm{C}\right)$

Oksidasi atau pembakaran arang merupakan reaksi terpenting yang terjadi didalam gasifier. Oksigen yang dipasok kedalam gasifier bereaksi dengan bahan yang mudah terbakar. Hasil reaksi tersebut adalah $\mathrm{CO}_{2}$ dan $\mathrm{H}_{2} \mathrm{O}$ yang secara berurutan direduksi ketika kontak dengan arang yang diproduksi pada pirolisis.

d. Reduksi $\left(50^{\circ} \mathrm{C}<\mathrm{T}<120^{\circ} \mathrm{C}\right)$

Reduksi merupakan tahapan gasifikasi yang melibatkan suatu rangkaian reaksi endotermik yang didukung oleh panas, serta diproduksi dari reaksi pembakaran. Produk yang dihasilkan pada proses ini adalah gas bakar, seperti: $\mathrm{H}_{2}, \mathrm{CO}, \mathrm{CH}_{4}$.

\section{Sekam Padi}

Sekam padi merupakan lapisan keras yang meliputi bulir beras yang terdiri dari dua belahan yang disebut lemma dan palea yang saling bertautan. Pada proses penggilingan beras sekam akan terpisah dari butir beras dan menjadi bahan sisa atau limbah penggilingan. Sekam dikategorikan sebagai biomasa yang dapat digunakan untuk berbagai kebutuhan seperti bahan baku industri, pakan ternak dan energi atau bahan bakar.

Sekam padi adalah salah satu energi alternatif yang dapat digunakan untuk menanggulangi krisis energi yang terjadi saat ini khususnya di daerah pedesaan. Energi sekam padi tidak hanya jumlahnya berlimpah tetapi juga merupakan energi terbaharukan, tidak seperti sumber bahan bakar fosil yang jumlahnya terbatas dan bukan merupakan energi terbarukan. Ketersediaan sekam padi di hampir 75 negara di dunia diperkirakan sekitar 100 juta ton dengan energi potensial berkisar 1,2 x $109 \mathrm{GJ} /$ tahun dan mempunyai nilai kalor rata-rata 15 $\mathrm{MJ} / \mathrm{kg}[6]$.

\section{Pembakaran}

Pembakaran adalah proses oksidasi yang sangat cepat antara bahan bakar dan oksidator dengan menimbulkan nyala dan panas. Bahan bakar merupakan substansi yang melepaskan 
panas ketika dioksidasi dan secara umum mengandung karbon, hidrogen, oksigen dan sulfur. Sementara oksidator adalah segala substansi yang mengandung oksigen yang akan bereaksi dengan bahan bakar [7].

Tujuan dari pembakaran adalah melepaskan seluruh panas yang terdapat dalam bahan bakar. Berdasarkan gas sisa yang dihasilkan, pembakaran dibedakan menjadi dua macam yaitu:

1. Pembakaran sempurna, yaitu pembakaran yang terjadi dimana seluruh bahan yang terbakar membentuk gas karbondioksida $\left(\mathrm{CO}_{2}\right)$, dan air $\left(\mathrm{H}_{2} \mathrm{O}\right)$ sehingga tidak ada lagi bahan yang tersisa.

2. Pembakaran tidak sempurna, yaitu pembakaran yang terjadi apabila hasil dari pembakaran berupa gas karbon monoksida $(\mathrm{CO})$ dan gas lain, dimana salah satu penyebanya adalah kekurangan oksigen.

Reaksi dari unsur-unsur bahan bakar dalam proses pembakaran sempurna adalah:

a. Pembakaran karbon menjadi karbon dioksida

$$
\mathrm{C}+\mathrm{O}_{2} \longrightarrow \mathrm{CO}_{2}
$$

Untuk membakar $12 \mathrm{~kg}$ karbon memerlukan $32 \mathrm{~kg}$ oksigen untuk membentuk karbon dioksida, oleh karen itu $1 \mathrm{~kg}$ karbon memerlukan 32/12 atau 2,67 kg mol oksigen dalam pembakaran.

b. Pembakaran hidrogen menjadi air

$2 \mathrm{H}_{2} \mathrm{O}+\mathrm{O}_{2} \longrightarrow \mathrm{H}_{2} \mathrm{O}$

Untuk membakar $4 \mathrm{~kg}$ hidrogen memerlukan $32 \mathrm{~kg}$ oksigen, oleh karena itu $1 \mathrm{~kg}$ hidrogen memerlukan 32/4 atau $8 \mathrm{~kg}$ oksigen untuk membentuk air.

Reaksi pembakaran dalam proses gasifikasi sekam padi (pembakaran tidak sempurna karena kekurangan oksigen) adalah:

\section{Reaksi Pembakaran Sekam Padi $\left(\mathrm{C}_{6} \mathrm{H}_{10} \mathrm{O}_{5}\right)$}

Sekam padi $\left(\mathrm{C}_{6} \mathrm{H}_{10} \mathrm{O}_{5}\right)$ direaksikan dengan oksigen murni $\left(\mathrm{O}_{2}\right)$ akan melepaskan satu molekul karbon dioksida $\left(\mathrm{CO}_{2}\right)$, empat molekul karbon monoksida (4CO), satu molekul metana $\left(\mathrm{CH}_{4}\right)$ dan tiga molekul air $\left(3 \mathrm{H}_{2} \mathrm{O}\right)$.

$\mathrm{C}_{6} \mathrm{H}_{10} \mathrm{O}_{5}+2 \mathrm{O}_{2} \longrightarrow \mathrm{CO}_{2}+4 \mathrm{CO}+\mathrm{CH}_{4}+3 \mathrm{H}_{2} \mathrm{O}$

Sekam padi $\left(\mathrm{C}_{6} \mathrm{H}_{10} \mathrm{O}_{5}\right)$ direaksikan dengan udara $\left(\mathrm{O}_{2}+3,76 \mathrm{~N}_{2}\right)$ akan melepaskan empat molekul karbon monoksida (4CO), dua molekul hidrogen $\left(2 \mathrm{H}_{2}\right)$, satu molekul metana $\left(\mathrm{CH}_{4}\right)$, satu molekul air $\left(\mathrm{H}_{2} \mathrm{O}\right)$, satu molekul karbon dioksida $\left(\mathrm{CO}_{2}\right)$ dan 3,76 molekul nitrogen $\left(3,76 \mathrm{~N}_{2}\right)$.

$\mathrm{C}_{6} \mathrm{H}_{10} 0_{5}+\left(\mathrm{O}_{2}+3,76 \mathrm{~N}_{2}\right) \longrightarrow 4 \mathrm{CO}+2 \mathrm{H}_{2}+\mathrm{CH}_{4}+\mathrm{H}_{2} \mathrm{O}+\mathrm{CO}_{2}+3,76 \mathrm{~N}_{2}$

\section{Gas metana}

Metana adalah hidrokarbon yang berbentuk gas dengan rumus kimia $\mathrm{CH}_{4}$. Metana murni tidak berbau, tapi jika digunakan untuk keperluan komersial, biasanya ditambahkan sedikit bau belerang untuk mendeteksi kebocoran yang mungkin terjadi.

Reaksi pembakaran gas metana dengan oksigen murni. 
ISSN: 1411-4348

$$
\mathrm{CH}_{4}+2 \mathrm{O}_{2} \longrightarrow \mathrm{CO}_{2}+2 \mathrm{H}_{2} \mathrm{O}
$$

Reaksi pembakaran gas metana dengan udara di alam.

$$
\mathrm{CH}_{4}+2 \mathrm{O}_{2}+7.52 \mathrm{~N}_{2} \longrightarrow \mathrm{CO}_{2}+2 \mathrm{H}_{2} \mathrm{O}+7.52 \mathrm{~N}_{2}
$$

\section{METODE PENELITIAN}

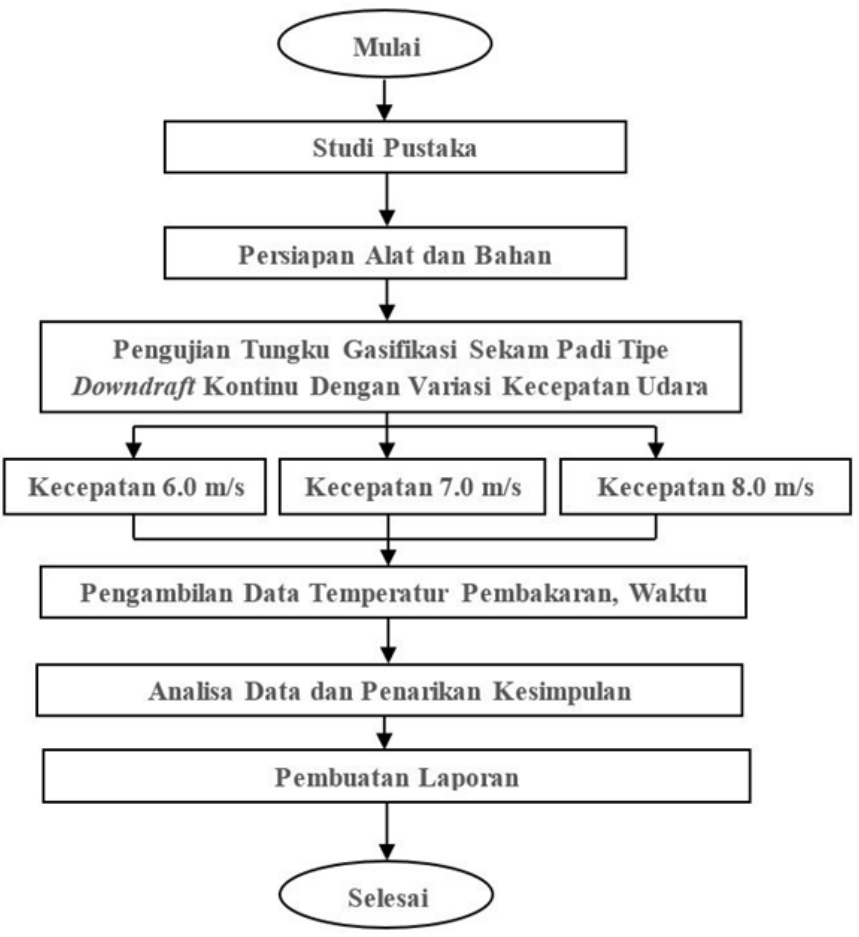

Gambar 4. Diagram alir penelitian

\section{Instalasi Pengujian}

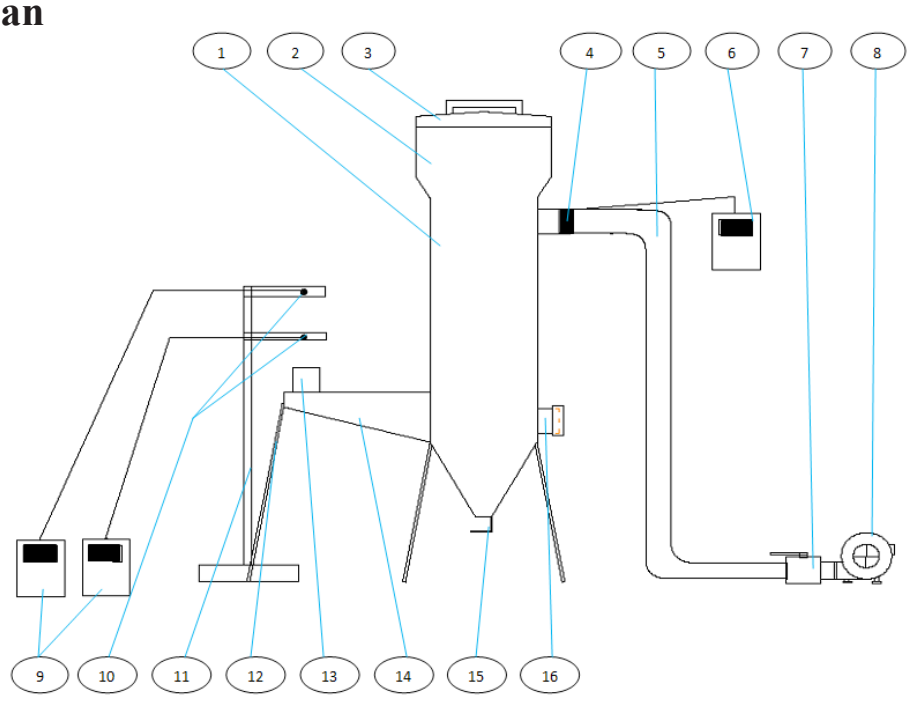

Keterangan:

Gambar 5. Instalasi Pengujian

1. Tungku pembakaran utama, sebagai tempat pembakaran bahan bakar untuk proses gasifikasi.

2. Storage (tangki pengisian), penampung suplai bahan bakar ke tungku utama.

3. Penutup tangki. 
4. Anemometer, digunakan untuk mengukur kecepatan udara yang akan masuk ke dalam tungku.

5. Saluran udara.

6. Anemometer reader, alat untuk membaca dan mendisplai hasil dari yang ditangkap sensor anemometer.

7. Katub pengatur, untuk mengatur dan mengunci kecepatan udara.

8. Blower, sebagai penyuplai udara.

9. Thermocouple reader, alat yang berfungsi untuk membaca dan mendisplai hasil yang didapat thermocouple.

10. Thermocouple, untuk mengukur temperatur dari nyala api yang dihasilkan.

11. Dudukan thermocouple.

12. Kaki penyangga tungku.

13. Saluran keluar gas, sebagai tempat keluar gas hasil gasifikasi.

14. Saluran penghubung.

15. Penahan ash chamber, menahan sekam sisa hasil gasifikasi .

16. Saluran ignition, untuk penyalaan awal

\section{HASIL DAN PEMBAHASAN}

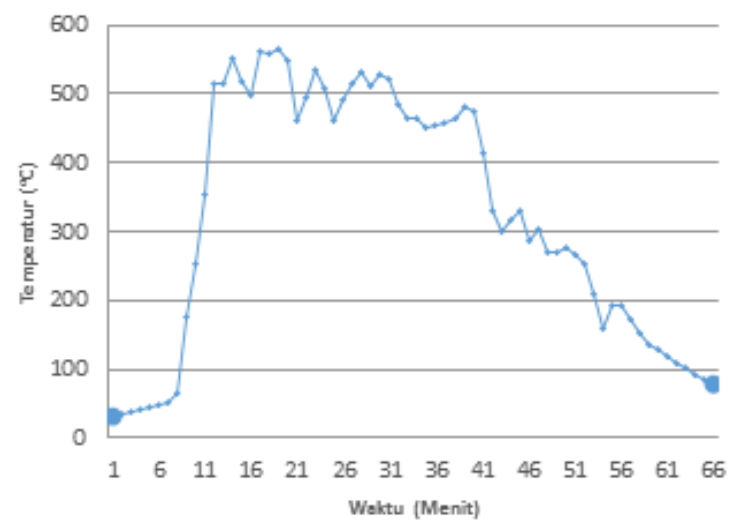

Gambar 6. Hubungan antara temperatur pembakaran dengan waktu pada kecepatan udara $6,0 \mathrm{~m} / \mathrm{s}$

Pada gambar 6 diatas menunjukkan bahwa, pada pengujian dengan menggunakan kecepatan udara $6,0 \mathrm{~m} / \mathrm{s}$ gas hasil gasifikasi mulai menyala pada menit ke- 9.5 , rata-rata temperatur nyala tertinggi yang dihasilkan adalah sebesar $500.47{ }^{\circ} \mathrm{C}$. Setelah melewati menit ke-44 terjadi penurunan temperatur hal ini terjadi dikarenakan pembakaran gas hasil gasifikasi bahan bakar sekam padi telah habis, sehingga temperatur mulai turun.

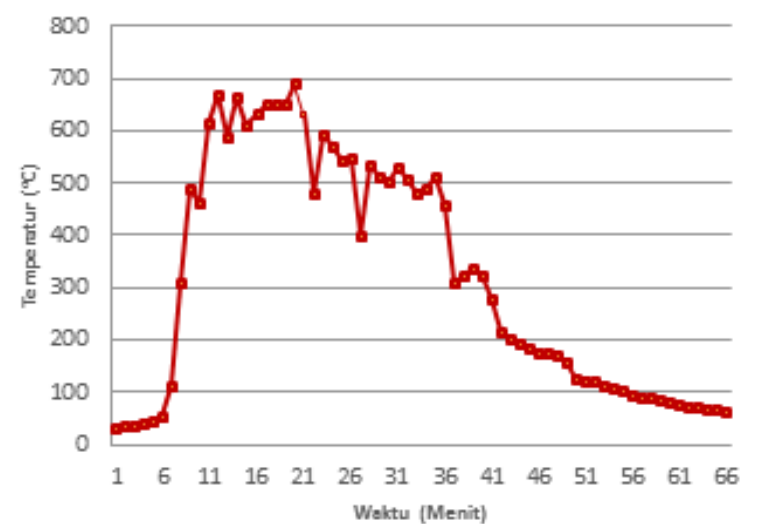

Gambar 7. Hubungan antara temperatur pembakaran dengan waktu pada kecepatan udara 7,0 m/s 
Pada gambar 7 menjelaskan tentang pengujian pembakaran gasifikasi dengan menggunakan kecepatan udara 7,0 m/s gas hasil gasifikasi mulai menyala pada menit ke-7, temperatur rata-rata tertingginya mencapai $559.51{ }^{\circ} \mathrm{C}$. Terjadi penurunan temperatur secara berangsur-angsur setelah melewati menit ke-39 ini terjadi dikarenakan gas yang dihasilkan dari proses gasifikasi bahan bakar sekam padi telah habis.

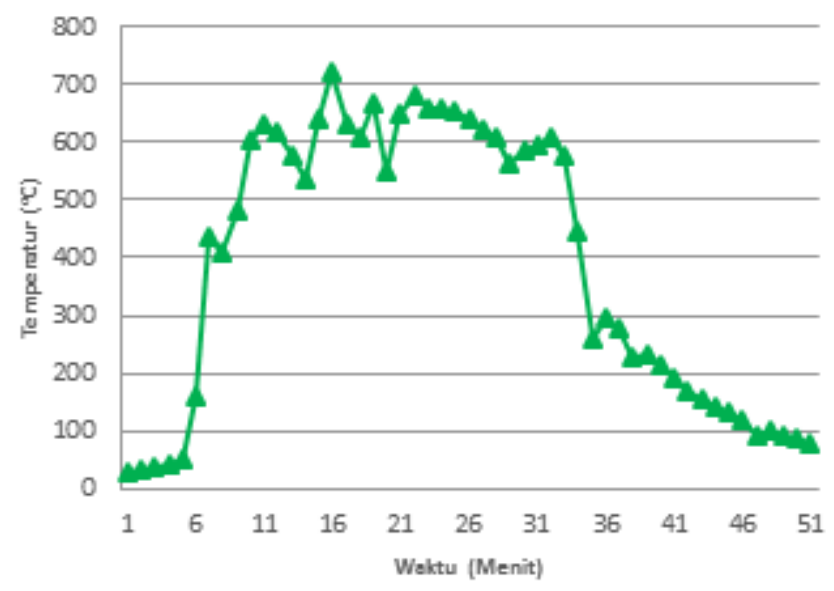

Gambar 8. Hubungan antara temperatur pembakaran dengan waktu pada kecepatan udara $8,0 \mathrm{~m} / \mathrm{s}$

Pada gambar 8 hubungan temperatur dan waktu pada kecepatan $8,0 \mathrm{~m} / \mathrm{s}$ diatas didapat beberapa data yaitu pada pengujian dengan menggunakan kecepatan tersebut gas yang dapat terbakar mulai dihasilkan dan dapat menyala saat dibakar pada menit ke-5.5, temperatur nyala rata-rata tertinggi yang dihasilkan pada pengujian dengan kecepatan ini sebesar 595,32 ${ }^{\circ} \mathrm{C}$. Setelah melewati menit ke-33.5 terjadi penurunan temperatur.

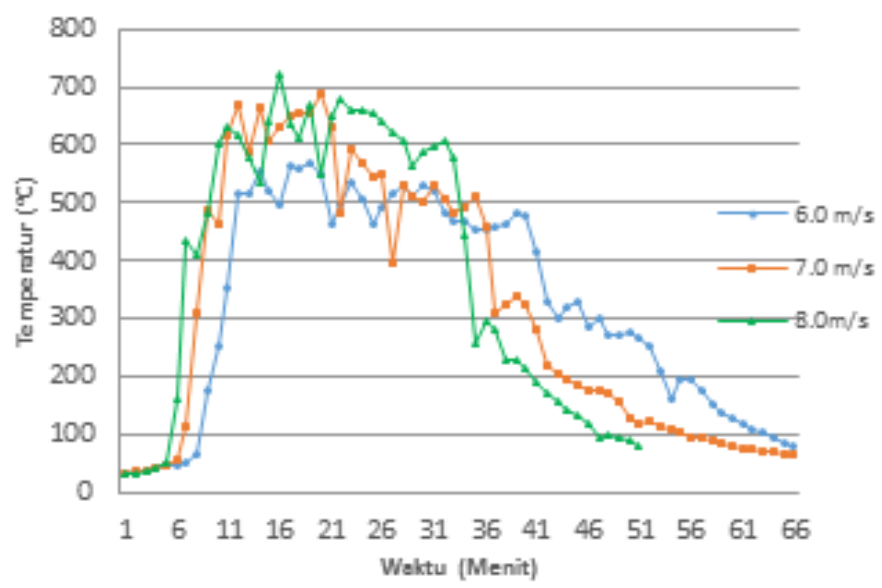

Gambar 9. Perbandingan temperatur pembakaran pada kecepatan udara $6,0 \mathrm{~m} / \mathrm{s}, 7,0 \mathrm{~m} / \mathrm{s}, 8,0 \mathrm{~m} / \mathrm{s}$

Pada gambar 9 grafik perbandingan antara ketiga variabel kecepatan yang digunakan dalam pengujian menunjukkan bahwa temperatur rata-rata tertinggi didapat pada kecepatan $8,0 \mathrm{~m} / \mathrm{s}$ yaitu sebesar $595,32{ }^{\circ} \mathrm{C}$, kemudian temperatur tertinggi setelahnya didapat pada pengujian dengan menggunakan kecepatan $7,0 \mathrm{~m} / \mathrm{s}$ yaitu sebesar $559,51{ }^{\circ} \mathrm{C}$ sedangkan temperatur yang terendah diantara ketiga variabel yang digunakan adalah pada kecepatan $6,0 \mathrm{~m} / \mathrm{s}$ yaitu sebesar $500,47{ }^{\circ} \mathrm{C}$. Semakin besar kecepatan udara yang digunakan maka temperatur rata-rata yang dihasilkan juga akan semakin tinggi. 


\section{Perbandingan Lama Waktu Penyalaan}

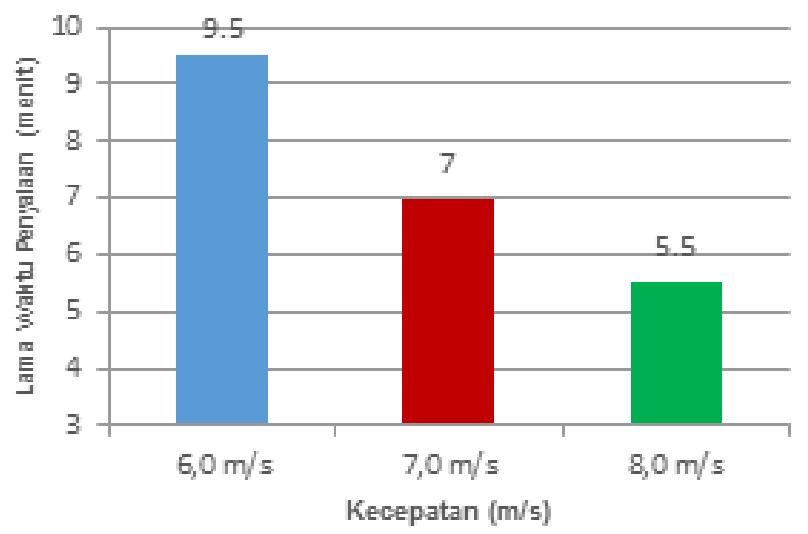

Gambar 10. Perbandingan lama waktu penyalaan pada kecepatan udara $6,0 \mathrm{~m} / \mathrm{s}, 7,0 \mathrm{~m} / \mathrm{s}, 8,0 \mathrm{~m} / \mathrm{s}$

Gambar 10 menunjukkan bahwa waktu yang dibutuhkan untuk dapat menghasilkan gas yang dapat terbakar dan dapat menyala paling cepat adalah pada kecepatan $8,0 \mathrm{~m} / \mathrm{s}$ yaitu selama 5,5 menit, kemudian pada kecepatan 7,0 m/s yaitu selama 7 menit dan yang paling lama diantara ketiga variabel yang digunakan adalah pada kecepatan udara $6,0 \mathrm{~m} / \mathrm{s}$ yaitu selama 9,5 menit. Semakin besar kecepatan udara yang digunakan maka waktu yang dibutuhkan untuk dapat menyala akan semakin cepat, sebaliknya semakin kecil kecepatan udara yang digunakan maka waktu penyalaan yang dibutuhkan akan semakin lama.

\section{Perbandingan Lama Nyala Efektif}

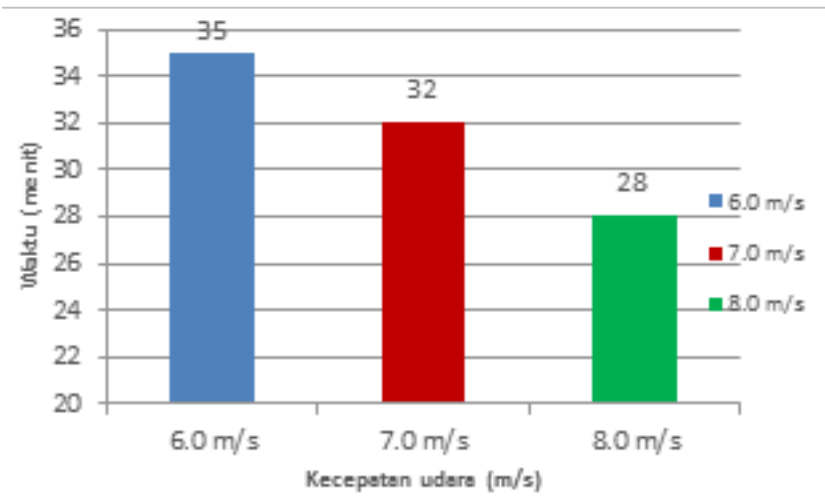

Gambar 11. Perbandingan nyala efektif pada kecepatan udara $6,0 \mathrm{~m} / \mathrm{s}, 7,0 \mathrm{~m} / \mathrm{s}, 8,0 \mathrm{~m} / \mathrm{s}$

Pada gambar 11 diagram batang menunjukkan bahwa, pada kecepatan udara $6,0 \mathrm{~m} / \mathrm{s}$ adalah kecepatan dengan nyala efektif paling panjang yaitu 35 menit kemudian kecepatan udara $7,0 \mathrm{~m} / \mathrm{s}$ selama 32 menit dan yang terpendek diantara ketiga varibel yang digunakan yaitu pada kecepatan udara $8,0 \mathrm{~m} / \mathrm{s}$ selama 28 menit. Semakin kecil kecepatan udara yang digunakan maka waktu nyala efektifnya akan lebih panjang, begitu pula sebaliknya semakin besar kecepatan udara yang digunakan maka waktu nyala efektifnya akan semakin pendek.

\section{KESIMPULAN}

Berdasarkan pembahasan dan analisa data dari pengujian tungku gasifikasi tipe downdraft kontinu dengan variasi kecepatan udara $6,0 \mathrm{~m} / \mathrm{s}, 7,0 \mathrm{~m} / \mathrm{s}$ dan $8,0 \mathrm{~m} / \mathrm{s}$, maka didapatkan kesimpulan sebagai berikut:

1. Variasi kecepatan udara berpengaruh terhadap temperatur pembakaran gas hasil 
gasifikasi, temperatur rata-rata tertinggi yaitu pada kecepatan udara $8,0 \mathrm{~m} / \mathrm{s}$ kecepatan $7,0 \mathrm{~m} / \mathrm{s}$ dan kecepatan $6,0 \mathrm{~m} / \mathrm{s}$.

2. Variasi kecepatan udara berpengaruh terhadap lama waktu penyalaan awal, waktu penyalaan tercepat yaitu pada kecepatan udara $8,0 \mathrm{~m} / \mathrm{s}$, kecepatan udara $7,0 \mathrm{~m} / \mathrm{s}$ dan kecepatan udara $6,0 \mathrm{~m} / \mathrm{s}$

3. Variasi kecepatan udara berpengaruh terhadap waktu nyala efektif yang dihasilkan, nyala efektif terpanjang yaitu pada kecepatan udara $6,0 \mathrm{~m} / \mathrm{s}$, kecepatan udara 7,0 m/s dan kecepatan udara $8,0 \mathrm{~m} / \mathrm{s}$

\section{DAFTAR PUSTAKA}

[1] Najib, Lailun, Darsopuspito, Sudjud, 2012, "Karakterisasi Proses Gasifikasi Biomassa Tempurung Kelapa Sistem Downdraft Kontinyu Dengan Variasi Perbandingan UdaraBahan Bakar (Afr) Dan Ukuran Biomassa”, Jurusan Teknik Mesin, Fakultas Teknologi Industri, Institut Teknologi Sepuluh Nopember, Surabaya

[2] Setiawan, Budi, 2014, "Studi Gasifikasi Batu Bara Lignite Dengan Variasi Kecepatan Udara Untuk Keperluan Karbonasi”, Jurusan Teknik Mesin, Fakultas Teknik, Universitas Muhammadiyah Surakarta, Surakarta

[3] Handoyo, 2013, "Pengaruh Variasi Kecepatan Udara Terhadap Temperatur Pembakaran Pada Tungku Gasifikasi Sekam Padi”, Jurusan Teknik Mesin, Fakultas Teknik, Universitas Muhammadiyah Surakarta, Surakarta

[4] Febijanto, Irhan, 2007, "Potensi Biomasa Indonesia Sebagai Bahan Bakar Pengganti Energi Fosil", BPPT, Jakarta

[5] http://www.enggcyclopedia.com

[6] Samsudin, Anis, dkk., 2009, "Studi Eksperimen Pemanfaatan Sekam Padi sebagai Bahan Bakar Gasifikasi Penghasil Syngas", Fakultas Teknik Universitas Negeri Semarang, Semarang

[7] Agung W, Wusan, dkk., 2010, “Gasifikasi Tempurung Kelapa Menggunakan Updraft Gasifier pada Beberapa Variasi Laju Alir Udara Pembakaran”, Jurusan Teknik Kimia, Fakultas Teknik, Universitas Sebelas Maret, Surakarta 